\title{
STRATEGI PENINGKATAN KOMPETENSI ASATIDZ DAN ASATIDZAH AL- QUR'AN DALAM PEMBELAJARAN TAHFIDZ QUR'AN MENYONGSONG REVOLUSI INDUSTRI 5.0
}

\author{
Heny Kusmawati \\ Sekolah Tinggi Agama Islam Pati \\ kusmawati.heny@gmail.com
}

\begin{abstract}
Islam is one of the religions of rahmatan lil alamin and religion that can shape the human being as khalifah fil ard. This is in line with the 5.0 industrial revolution that is being adopted in Japan where society is the basis of the development of the industrial revolution. Under the industrial revolution 4.0, the teacher already faces problems with technological development. In Islam, this is highly recommended to be able to master technology. One problem of teacher competencies is when technology becomes a reason for someone unwilling to memorize. At least the output of the Quran generation is capable of being globally competence teachers. This paper discusses the improvement of original and authentic competencies in facing the 5.0 industrial revolution. Efforts to improve teachers are carried out by conducting training of English language, leadership or managerial services following the modern era, updating boarding facilities through the latest technology, continuing professional enhancement and lesson study with the support of e-literacy, and regulations on teacher competency standards in Indonesia.
\end{abstract}

Keywords: Competence, Learning, Tahfidz, 5.0 Revolution

\section{Pendahuluan}

Seperti rollercoaster, umat Islam yang dulunya berada di atas puncak kejayaan, kini ternyata sedang dalam titik nadir. Masa-masa keemasan yang dulunya menghiasi lembaran sejarah umat manusia, sekarang hanya menjadi nostalgia manis pengisi kenangan umat muslim. Apa yang telah terjadi? Apa yang menyebabkan? Dan mengapa harus terjadi?

Boleh jadi salah satu penyebab utama persoalan adalah kian menjauhnya umat dari nilai-nilai yang dikandung Al-Qur'an dan As-sunnah. Seolah menjadi fenomea gunung es bahwa umat muslim lebih gencar menghembuskan paham-paham duniawi. Bukannya menangkal paham tersebut justru umat muslim senang hati menyambutnya dan perlahan namun pasti umat muslim digiring menjauhi Al-Qur'an dan perlahan membentuk pola pikir "cinta dunia dan takut mati". Padahal, sejarah Islam dengan masa keemasan tidak akan pernah terjadi tanpa memahami dan mengamalkan Al.Quran secara totalitas. Apalagi, desakan revolusi industri 4.0 yang sedang dijalani oleh negara Indonesia telah membawa dampak yang tidak sederhana mengenai seluruh aspek kehidupan manusia. Termasuk dalam hal ini adalah pendidikan dan pembelajaran yang memposisikan semakin sentralnya peran teknologi cyber dalam kehidupan manusia sehingga di dalam dunia pendidikan muncul istilah "Pendidikan 4.0"dan tentunya dalam pembelajaran tahfidzul qur'an juga mengalami pergeseran paradigma dimana orang selalu menggunakan kata sibuk untuk menjadikannya sebuah alasan untuk tidak menghafalkan al.Qur'an. 
Semakin sedikitnya kaum muslim yang menghafalkan qur'an maka semakin sedikit juga asatidz qur'an yang memiliki kompetensi inti keilmuan yang kuat dalam bidang tahfidzul qur'an. Seperti yang diketahui bahwa kata asatidz adalah bentuk jamak dari kata $u s t a d z$ yang berarti tenaga pendidik yang khusus diangkat dengan tugas mengajar. Adapun pengertian pendidik, menurut istilah yang lazim digunakan masyarakat, telah dikemukakan oleh ahli pendidikan.Ahmad Tafsir, misalnya mengatakan bahwa pendidik dalam pendidikan Islam sama dengan teori barat yaitu siapa saja yang bertanggung jawab terhadap perkembangan anak didik. Selanjutnya ia mengatakan bahwa dalam Islam orang yang bertanggungjawab tersebut adalah orang tua anak didik dan tanggung jawab itu sekurangkurangnya disebabkan oleh dua hal. Pertama, karena kodrat, kedua karena kepentingan kedua orang tua yaitu berkepentingan terhadap perkembangan anak. Suksesnya anaknya adalah suksesnya orangtuanya juga ${ }^{1}$

Terkait hal tersebut, kesuksesan anak dalam pembelajaran tahfidzul qur'an merupakan salah satu keinginan orang tua ketika menitipkan anaknya pada asatidz qur'an . Maka, sebagai penyumbang ilmu, seorang guru (asatidz dan asatidzah) al-quran pun dituntut untuk berilmu. Agar apa yang disampaikan pada peserta didik dapat menjadi perantara datangnya kebaikan-kebaikan, alih-alih sebagai pemicu kerusakan. Untuk itu, guru harus terus meningkatkan kapasitas keilmuannya terlebih lagi asatidz al.qur'an karena memiliki amanat yang lebih berat dibandingkan dengan guru-guru lainnya.Tidak hanya sebagai pengisi gelas kosong asatidz al-quran tetapi juga harus mampu menjadi contoh dan mampu menginspirasi. Mengacu kepada negara Jepang yang sudah menggunakan konsep "Society 5.0" ini, manusia akan berperan lebih besar dengan mentransformasi big data menjadi suatu kearifan baru yang pada akhirnya meningkatkan kemampuan manusia untuk membuka peluang -peluang bagi kemanusian demi tercapainya kehidupan bermakna ${ }^{2}$. Disinilah korelasi yang relevan asatidz al-qur'an sebagai manusia yang berperan dalam menyampaikan informasi kearifan dan kebenaran al-qur'an pada umat Islam.

\section{Urgensi Kompetensi Asatidz dan Asatidah Al.Qur'an di Revolusi Industri 5.0}

Konsep Society 5.0 telah digaungkan oleh Negara Jepang saat ini. Bagi mereka, tanpa bantuan teknologi digital akan sulit untuk melayani dan memenuhi semua kebutuhan masyarakatnya mengingat semakin sedikitnya jumlah populasi produktif. Dapat diketahui bahwa Negara Jepang khususnya akan semakin terkenal di dunia dengan memanfaatkan internet of things, big data, artificial intelligence (AI), robot, dan sharing economy plus berfokus pada humanisme. Lalu, Society 5.0 ini menjadi sebuah cetak biru dan strategi masa depan yang sangat sesuai mendobrak kegilaan negara-negara selain Negara Jepang akan Revolusi Industri 4.0. Di tengah banyaknya pekerjaan yang hilang karena otomatisasi dan kapitalisme yang bertepuk sebelah tangan dikarenakan efektifitas dan efisiensi bisa diwujudkan, Society 5.0 menjadi angin segar perubahan.Perlu dipahami juga, bahwa ini merupakan sebuah perjalanan panjang untuk mewujudkannya. Negara Jepang akan menunjukkan pada dunia bahwa Society 5.0 ini akan sukses dan pelan-pelan memasuki negara-negara lain yang saat ini masih dan akan fokus pada Revolusi Industri 4.0 Di saat Jepang mengalami defisit populasi, Indonesia justru berkebalikan. Indonesia akan mengalami apa yang disebut sebagai bonus demografi pada 2020-2045. Mengapa disebut bonus? Karena pada saat itu angkatan usia produktif (15-64 tahun) diprediksi mencapai 68\% dari total

${ }^{1}$ Ahmad Tafsir, Ilmu Pendidikan Dalam Persepektif Islam (Bandung: PT Remaja Rosdakarya, 1991),

2 M.Diaz Bony Supramono, Urgensi Society 5.0 di Era Revolusi Industri 4.0 dalam https://www.kompasiana.com/diaz.bonny/5c4f90f5677ffb5363300e24/urgesi-society-5-0-di-era-revolusiindusti-4-0 diakses pada 6 April 2019 jam 13.13 
populasi dan angkatan tua (65+) sekitar 9\%. Setelah tahun 2045 dan seterusnya akan terjadi penurunan dan memasuki era aging society (generasi tua). Justru kedua momentum ini harus digabungkan menjadi sebuah blue print nasional agar tidak terlambat menyadari generasi yang terus menua seperti Rusia, Korea, Singapura dan Jepang ${ }^{3}$.

Islam juga harus mampu mengadopsi society 5.0 dimana generasi qur'ani harus mampu mempelajari, memahami, dan menerjemahkan Al.Qur'an sebagai pedoman kehidupan. Disini peranan asatadiz dan asatidzah al-quran sangat dibutuhkan. Kompetensi yang relevan dengan era revolusi 5.0 harus mulai dipersiapan. Seperti yang diketahui didalam pendidikan Islam, kompetensi guru pendidikan agama Islam ada empat yakni kompetensi paedagogik, kepribadian, profesionalisme, dan sosial. Dalam keempat kompetensi tersebut di adopsi bahwa sosok guru itu harus menguasai materi pelajaran, memiliki kepribadian yang baik, profesional terhadap profesinya dalam artian tidak mencampur adukkan kepentingan pribadi dan kepentingan umum ketika mengajar, dan memiliki kompetensi sosial yang sesuai dengan lingkungan dan mata pelajaran yang diampu sehingga tidak kontra dengan nila-nilai dimasyarakat. Lalu apakah sama dengan kompetensi asatidz dan asatidzah al-quran?

Asatidz dan asatidzah al-qur'an adalah guru yang mengajar al-quran dan memiliki kemampuan untuk mengajar tahfidz al-qur'an kepada santri-santrinya. Adapun kompetensinya adalah sebagai berikut:

1. Menghiasi diri dengan akhlak terpuji ${ }^{4}$

Seorang guru seyogyanya menghiasi diri dengan kebaikan - kebaikan yang ditentukan oleh syariat. Sikap dan sifat yang terpuji lagi diridhoi contohnya, seperti zuhud terhadap dunia dan hanya mengambil sedikit saja darinya, tidak diambil pusing terhadap dunia dan para penghulunya; dermawan lagi berakhlak; menampakan kegembiraan tanpa melampaui batas kesopanan, kebijaksanaan dan kesabaran; besar hati terhadap rendahnya pendapatan dengan membiasakan sikap wara', kyusuk, tenang, rendah hati, serta tunduk. Tidak banyak tertawa dan bercanda. Membiasakan pengamalan syariat, seperti kebersihan dengan menghilangkan kotoran dan rambutrambut yang diperintahkan syariat untuk menghilangkannya seperti mencukur kumis. Menghilangkan bau tak sedap. Memotong kuku, memanjangkan jenggot, ataupun tidak memakai pakaian yang dibenci syariat.

Jika dikaitkan dengan revolusi 5.0 maka kompetensi sangat berhubungan dengan kebijakan asatidz dan asatidzah dalam berperilaku dan menggunakan teknologi seperti sosial media untuk media berdakwah tentang ayat-ayat al-quran. Hendaknya menggunakan hadits- hadits sebagai pedoman dalam bertasbih, bertahlil, ataupun dalam mengamalkan doa dan dzikir dan menamankan perasaan selalu diawasi oleh Allah baik dalam melakukan hal-hal yang tampak maupun tidak tampak, dan mempercayakan segala urusannya pada Allah Ta'ala.

\section{Kemampuan Ahlul Qur'an}

Meminjam istilah tasawuf, term mursyid untuk pembimbing menghafal alQur'an. Seorang mursyid harus hafiz al-Qur'an. Bimbingan yang dilakukan oleh

\footnotetext{
${ }^{3}$ M Diaz Bony Supramono, Urgensi Society 5.0 di Era Revolusi Industri 4.0 ...diakses pada 6 April 2019 jam 13.13

${ }^{4}$ Imam Abu Yahya Bin Syaraf An-Nawawi, At-Tibyan Adab Para Penghafal Al-Qur'an, Terj. Umniyyati Sayyidatul Hauro' dkk.(Sukoharjo: Alqowam, 2005), 31.
} 
mursyid biasanya diwujudkan dalam bentuk menerima setoran hafalan, mengontrol, dan mengkondisikan hafalan, memberikan arahan, saran, motivasi, dan memeriksa bacaan dan kemampuanya telah di akui oleh gurunya dengan ijzah maupun sanad. Pembimbing tahfidz tertentu harus menguasai ilmu tajwid juga menguasai makhrojul huruf dengan baik dan benar. Mendisiplinkan mursyid karena keberhasilan murid dalam menghafal juga tergantung bagaimana pembimbing mengarahnya dengan tepat ${ }^{5}$

\section{Kemampuan Habblu Minannas}

a. Memperlakukan murid dengan baik

Seorang guru seyogyanya bersikap baik pada orang yang belajar padanya, menyambutnya ketika datang dan bersikap baik padanya sesuai kondisi keduanya. Abu Harun Al Abdi berkata 'kami pernah mendatangi Abu Said al Khudri ra. Dan saat itu ia mengatakan: selamat datang wasiat rasulullah ${ }^{6}$

b. Mendahulukan giliran yang lebih dahulu datang

Jika muridnya banyak, hendaknya guru mendahulukan giliran murid yang pertama kali datang dan seterusnya. Jika yang pertama rela didahulukan maka tidak mengapa ia mendahulukan yang lain

c. Hendaknya guru membiasakan sikap empati

Seperti menanyakan kehadiran, menanyakan keadaan, membiasakan memberikan motivasi, dan memasang wajah ceria.

d. Komunikasi antar asatidz al-qur'an

Menjalin relasi yang baik dengan guru untuk saling bertukar pendapat, wawasan, dan bertambahnya ilmu

4. Muallim sebagai pendidik akhlakul karimah

Asatidz dan asatidzah hendaknya memberi tahu peserta didik dan memotivasi sehingga terbukanya gerbang-gerbang pengetahuan, lapang dada, memancar dari hatinya mata air hikmah dan kelembutan, diberkati ilmu dan keadaanya serta dituntun perkataan dan perbuatannya oleh Allah.

Dengan penjelasan diatas, lebih rincinya bahwa seorang asatidz dan asatidzah adalah orang yang harus mampu membimbing peserta didik dalam pembelajaran tahfidz dengan sedikitnya adalah empat kompetensi dibawah ini:

\begin{tabular}{|l|l|l|}
\hline No & Kompetensi Guru Umum & Kompetensi Guru Tahfidz \\
\hline 1 & Kepribadian & Menghiasi diri dengan akhlak terpuji \\
\hline 2 & Profesional & Kemampuan ahlul al-quran \\
\hline 3 & Sosial & Kemampuan habblu minannas \\
\hline
\end{tabular}

\footnotetext{
${ }^{5}$ D.M Makhyaruddin, Rahasia Nikmatinya Menghafal Al-Qur'an (Jakarta: Mizan Publika, 2013), 84

${ }^{6}$ Imam Abu Yahya BinSyaraf An Nawawi,At-Tibyan, 31
} 


\begin{tabular}{|l|l|l|}
\hline 4 & Paedagogik & Mualim sebagai pendidik \\
\hline
\end{tabular}

\section{Faktor-Faktor Yang Mempengaruhi Kompetensi Asatidz dan Asatidzah}

Sebuah kompetensi mampu bertahan atau berkembang karena faktor-faktor tertentu. Didalam kompetensi asatidz dan asatidzah juga dipengaruhi faktor dibawah ini:

1. Faktor-Faktor yang Mempengaruhi Kompetensi Sosial .Adapun faktor-faktor yang mempengaruhi kompetensi sosial guru antara lain $:^{7}$

a. Keluarga. Keluarga merupakan lingkungan pertama yang memberikan pengaruh terhadap berbagai aspek perkembangan seseorang, termasuk perkembangan sosialnya.

b. Kematangan. Bersosialisasi memerlukan kematangan fisik dan psikis. Untuk mampu mempertimbangkan dalam proses sosial, memberi dan menerima pendapat orang lain, memerlukan kematangan intelektual dan emosional, disamping itu kemampuan berbahasa ikut pula menentukan.

c. Pendidikan. Pendidikan merupakan proses sosialisasi anak yang terarah. Pendidikan dalam arti luas harus diartikan bahwa perkembangan anak dipengaruhi oleh kehidupan keluarga, masyarakat dan kelembagaan. Penanaman norma perilaku yang benar secara sengaja diberikan kepada peserta didik yang belajar di lembaga pendidikan. Disana siswa dikenalkan kepada norma-norma lingkungan dekat, norma kehidupan bangsa dan norma kehidupan antar bangsa. Dengan demikian seseorang yang telah mendapatkan pendidikan setidaknya mampu berinteraksi dan bersosialisasi dengan baik dalam masyarakat. ${ }^{8}$

Adopsi kompetensi sosial dimana kontribusi keluarga, kematangan, dan pendidikan merupakan salah satu aspek terbesar dalam human society. Dengan pemikiran bahwa apabila seorang memiliki pola asuh yang demokrasi maka kemampuan dalam bersosialisai juga akan meningkat dan mampu mempengaruhi pendidikan yang akan berdampak pada lingkungan sekelilingnya. Asatidz dan asatidzah juga mengalami hal tersebut. Dimana ia dilahirkan itulah yang akan membentuk kompetensi sosial yang berhubungan dengan intrapersonal, kemudian kematangan akan mempengaruhi kemampuan bahasa seorang asatidz dan asatidzah yang dibutuhan adalah bahasa inggris dan arab karena hafalan alquran berhubungan dengan bahasa asing, dan pendidikan ini berhubungan dengan interpersonal

${ }^{7}$ Sunarto dan B. Agung Hartono, Perkembangan Peserta didik ( Jakarta: Depdiknas dan PT Cipta 1999), 130.

${ }^{8}$ Sunarto dan B. Agung Hartono, Perkembangan Peserta didik., 132. 
2. Faktor yang mempengaruhi kompetensi kepribadian dipengaruhi oleh:

a. Faktor biologis atau bawaan. Faktor yang dibawa orang sejak lahir.

b. Faktor sosial termasuk ke dalam faktor sosial ini juga tradisi-tradisi, adat istiadat, peraturan-peraturan, bahasa, dan sebagainya yang berlaku dalam masyarakat itu. ${ }^{9}$

c. Faktor kebudayaan yaitu kebudayaan yang tumbuh dan berkembang di tengahtengah masyarakat. Sebenarnya faktor kebudayaan ini sudah termasuk dalam faktor sosial seperti yang telah diuraikan. Namun disini kita hendak membicarakan kebudayaan lebih luas, lengkap dan aspek-aspeknya mampu berinteraksi dan bersosialisasi dengan baik dalam masyarakat. ${ }^{10}$

d. Kapasitas mental: emosi dan intellegensi kemampuan berpikir banyak mempengaruhi banyak hal seperti kemampuan belajar, memecahkan masalah dan berbahasa. Perkembangan emosi berpengaruh terhadap perkembangan sosial seseorang. Seseorang yang mempunyai intelektual tinggi akan berkemampuan berbahasa secara baik. Oleh karena itu, kemampuan intelektual tinggi, kemampuan berbahasa yang baik dan pengendalian sosial secara seimbang sangat menentukan dalam perkembangan sosial, dimana setelah dewasa diharapkan si anak mudah bergaul dan membaur dengan masyarakat. ${ }^{11}$

3. Faktor yang mempengaruhi kompetensi pedagogik asatidz dan asatidzah diantaranya adalah

a. Latar belakang pendidikan guru ${ }^{12}$

Latar belakang pendidikan guru merupakan salah satu persyaratan yang diprioritaskan, guru yang memiliki latar belakang pendidikan keguruan mendapatkan bekal pengetahuan tentang pengelolaan kelas, proses belajar mengajar dan sebagainya. Sedangkan guru yang belum mengambil pendidikan keguruan, dia akan merasa kesulitan untuk dapat meningkatkan kualitas keguruannya.

b. Pengalaman mengajar asatidz dan asatidzah

Pengalaman akan sangat mempengaruhi kemampuan guru dalam menjalankan tugas dan peningkatan kompetensi guru. Bagi guru yang pengalaman mengajarnya baru beberapa tahun atau belum berpengalaman sama sekali, akan berbeda dengan guru yang berpengalaman mengajarnya telah bertahuntahun sehingga semakin lama dan semakin banyak pengalaman mengajar, tugasnya akan semakin baik dalam mengantarkan anak didiknya untuk mencapai tujuan belajar, sesuai hasil pengalamannya mengajar.

\footnotetext{
9 Sunarto dan B. Agung Hartono, Perkembangan Peserta didik, 89.

${ }^{10}$ Sunarto dan B. Agung Hartono, Perkembangan Peserta didik ,125.

${ }^{11}$ Sunarto dan B Agung Hartono, Perkembangan Peserta didik, 130.

${ }^{12}$ User Algesindo Usman, Menjadi Guru Professional, (Bandung: Remaja rosdakarya, 2001), 46
} 
c. Kesehatan guru

Kondisi jasmani yang sehat akan menghasilkan proses belajar mengajar sesuai yang diharapkan. Guru yang sehat akan dapat mengerjakan tugas-tugasnya dengan baik. Jasmani yang sehat harus didukung dengan rohani yang sehat pula, dengan mental dan jiwanya yang sehat maka guru dapat menjaga keseimbangan kebutuhan jasmani dan rohani.

\section{d. Penghasilan guru}

Perbaikan kesejahteraan ekonomi akan menumbuhkan semangat kerja asatidz dan asatidzah, sebaliknya ketika penghasilan tidak sesuai akan menurunkan semangat kerja asatidz dan asatidzah

e. Sarana pendidikan:

Sarana prasarana harus memadai agar memberikan motivasi kepada asatidz dan asatidzah dalam melakukan tugasnya dalam pembelajaran tahfidz

f. Disiplin dalam bekerja;

Dalam hal ini asatidz dan asatidzah harus mampu disiplin dan tegas dalam memberikan waktu untuk setoran alquran pada setiap peserta didik selain itu kedatangannya juga harus tepat waktu. Dalam hal ini pemimpin atau manajerial memiliki fungsi pengawasan.

\section{Pembelajaran Tahfidz Al-Qur'an}

1. Pengertian Pembelajaran Tahfidhul Qur'an

Pembelajaran adalah suatu sistem yang bertujuan untuk membantu proses belajar siswa, yang berisi serangkaian peristiwa yang dirancang, disusun sedemikian rupa untuk mempengaruhi dan mendukung terjadinya proses belajar siswa yang bersifat internal. ${ }^{13}$

Sementara itu, Tahfidz Al-Qur'an atau Tahfidzul Qur'an merupakan gabungan dari dua kata yang berasal dari bahasa Arab, yaitu tahfidz dan Al- Qur"ean. Kata tahfidz merupakan bentuk isim mashdar dari fiil madhi ( تحفيظ - يحفظ - حفظ ) yang mengandung makna menghafalkan atau menjadikan hafal. Dengan demikian Tahfidz Al-Qur'an atau tahfidzul Qur'an dapat berarti menjadikan (seseorang) hafal Al-Qur'an. Al-Qur'an berasal dari kata qara 'a artinya bacaan atau yang dibaca, sedangkan menurut istilah AlQur'an adalah kalam atau firman Allah yang diturunkan ( diwahyukan ) kepada Nabi Muhammad SAW. Melalui perantara malaikat Jibril yang diturunkan secara mutawatir sebagai pedoman umat manusia didunia dan membacanya termasuk ibadah. ${ }^{14}$

Menghafal Al-Qur'an merupakan fadhal (anugerah )dari Allah, namun bukan berarti tidak dapat kita upayakan. Untuk mampu menyelesaikan hafalan hingga 30 juz butuh persiapan, pelaksanaan, dan penjagaan yang ekstra. Jika menghafal Al-Qur'an

${ }^{13}$ Gagne dan Briggs ( 1979:3 )

${ }^{14}$ Muhammad Adnan, Ke Nuan MTs/SMP Kelas VIII ( LP: NU,2009), 9. 
ibarat sebuah perjalanan panjang, maka kita perlu menyiapkan bekal dan kebutuhan. ${ }^{15}$ Menurut Abdul Aziz Abdul Rauf definisi menghafal adalah "proses mengulang sesuatu, baila dengan membaca atau mendengar".

Pekerjaan apapun jika sering diulang pasti menjadi hafal. ${ }^{16} \mathrm{Jika}$ arti bahasa tidak berbeda dengan arti istilah dari segi membaca diluar kepala, maka menghafal Al-Quran berbeda dengan penghafal hadist, syair, hikmah dan lain-lainya dalam 2 pokok:

a. Hafal seluruh Al-Quran serta mencocokanya dengan sempurna Tidak bisa dikatakan al hafidz bagi orang yang hafalanya setengah atau sepertiganya secara rasional. Karena jika yang hafal setengah atau sepertiganya berpredikat al hafidz maka bisa dikatakan bahwa seluruh umat islam berpredikat al hafidz, sebab semuanya mungkin telah hafal surat al-fatihah, karena surat alfatihah merupakan salah satu rukun shalat dari kebanyakan madzhab. Maka istilah al hafidz (orang yang berpredikat hafal Al- Quran) adalah mutlak bagi orang yang hafal keseluruhan dengan mencocokan dan menyempurnakan hafalanya menurut aturan-aturan bacaan serta dasar-dasar tajwid yang masyhur.

b. Senantiasa terus menerusdan sungguh-sungguh dalam menjaga hafalan dari lupa. Seorang tahfidz harus hafal Al Quran seluruhnya. Maka apabila ada orang yang telah hafal kemudian lupa atau lupa sebagian atau keseluruhan karena lalai atau lengah tanpa alasan seperti ketuaan atau sakit, maka tidak dikatakan hafidz dan tidak berhak menyandang predikat "penghafal Al Quran". ${ }^{17}$

2. Metode Tahfidhul Qur'an

Menghafal al-Qur'an bukan usaha yang dapat dianggap mudah untuk dilakukan semua orang, hal ini karena banyaknya materi dan adanya hampir kesamaan antar ayat dan atauran-aturan dalam membaca. Untuk itu diperlukan metode-metode yang dapat membantu usaha kita untuk dapat menghafal al-Qur'an dengan benar. Adapun metodemetode tersebut yang perlu dilakukan, menurut Ahsin W. Al-Hafidz, ialah :

a. Metode Wahdah, yaitu menghafal satu persatu terhadap ayat-ayat yang hendak dihafalkannya.

b. Metode Kitabah, yaitu penghafal terlebih dulu menulis ayat-ayat yang akan dihafalkan pada secarik kertas yang telah tersedia.

c. Metode Gabungan, yaitu gabungan antara metode wahdah dan metode kitabah, hanya saja pada kitabah lebih berfungsi untuk uji coba terhadap ayat yang telah dihafalkan.

d. Metode Jama', yaitu cara menghafal yang dilakukan secara kolektif yang dipimpin oleh seorang instruktur. ${ }^{18}$

Metode Tahfidzul Qur'an lainnya juga dikemukakan oleh Abdurrab Nawabuddin, yaitu :

${ }^{15}$ Ulin Nuha Mahfudhon, Jalan Penghafal Al-Qur'an, (Jakarta: Kompas Gramedia, 2017). 18.

16 Abdul Aziz Abdul Rauf, Kiat Sukses Menjadi Hafidz Qur;an Daiyah, (Bandung: Syamil Cipta Media, 2004), 49.

${ }^{17}$ Abdu al-Rabb Nawabudin, Metode Efektif Menghafal al-Quran, (Jakarta: Tri Daya Inti, 1988), 17.

18 Ahsin W. Al-Hafidz, Bimbingan Praktis Menghafal Al-Qur'an, (Jakarta : Bumi Aksara, 1994), 22- 
a. Metode Juz'i, yaitu cara menghafal secara berangsur-angsur atau sebagian demi sebagian dan menghubungkannya antar bagian yang satu dengan bagian lainnya dalam satu kesatuan materi yang dihafal. Hal ini dapat dikaji dari pernyataan berikut ini: "Dalam membatasi atau memperingan beban materi yang akan dihafalkan hendaknya dibatasi, umpamanya menghafal sebanyak tujuh baris, sepuluh baris, satu halaman, atau satu hizb. Apabila telah selesai satu pelajaran, maka berpindahlah ke pelajaran yang lain kemudian pelajaran-pelajaran yang telah dihafal tadi satukan dalam ikatan yang terpadu dalam satu surat. Sebagai contoh seorang murid yang menghafal surat al-Hujurat menjadi dua tau tiga tahap, surat al-Kahfi menjadi empat atau lima tahap."

Selanjutnya dijelaskan bahwa: "Metode ini mempunyai suatu sisi negatif yaitu murid menemukan kesulitan dalam mengaitkan berbagai kondisi dan tempat yang berbeda. Dan untuk bisa menanggulangi hal ini dengan banyak membaca surat-surat sebagai satu bagian yang terpadu sehingga kesulitan murid akan berkurang sedikit demi sedikit dan pada akhirnya lenyap sama sekali."

Metode Juz'i tersebut menurut Abdurrab Nawabuddin merupakan suatu metode yang sangat baik untuk dipergunakan dalam proses menghafal al-Qur'an,hal itu dikarenakan adanya beberapa alasan, sebagai berikut :

1) Sebuah riwayat Al Baihaqi dari Abu Aliyah berkata: Nabi Muhammad saw menggunakan metode ini dalam mengajar qiro'ah para sahabatnya, begitu juga para sahabat mengajarkannya pada generasi selanjutnya.

2) Metode ini lebih utama atau lebih tepat untuk anak-anak dan orangorang yang kurang berpengalaman dalam hal menghafal al- Qur'an

3) Metode ini lebih baik untuk menghafal ayat-ayat yang mirip baik dalam struktur maupun dalam kata-kata serta ayat-ayat yang diulangulang, seperti dalam surat ar-Rahman, al-Waqi'ah, al-Jin, al-Mursalat, dan disamping hal-hal lain seperti diungkapkan dalam kenegatifan metode simultan. ${ }^{19}$

Dalam hadits yang disebutkan di atas menjelaskan bahwa Rasulullah mengajar al-Qur'an secara bertahap atau berangsur-angsur dalam penghafalannya, karena mengingat bahwa al-Qur'an terdiri atas enam ribuan ayat lebih.

a. Metode Kulli, yaitu metode menghafal al-Qur'an dengan cara menghafalkan secara keseluruhan terhadap materi hafalan yang dihafalkannya, tidak dengan cara bertahap atau sebagian-sebagian. Jadi yang terpenting keseluruhan materi hafalan yang ada dihafal tanpa memilah-milahnya, baru kemudian diulang-ulang terus sampai benar-benar hafal. Penjelasan tersebut berasal dari pernyataan berikut ini: "Hendaknya seorang penghafal mengulang-ulang apa yang pernah dihafalkannya meskipun hal itu dirasa sebagai suatu kesatuan tanpa memilah-milahnya. 


\section{$e^{\mathrm{L}-\text { Tarbauj }}$}

Misalnya dalam menghafal surat An-Nur, di sana ada tiga hizb, kurang lebih delapan halaman yang dapat dihafalkan oleh siswa sekaligus dengan cara banyak membaca dan mengulang.

Dari penjelasan di atas, maka dapat dinilai bahwa metode-metode yang dikemukakan oleh beberapa ahli di atas, sangat baik untuk saling melengkapi satu sama lainnya. Pada dasarnya terdapat suatu kesamaankesamaan mengenai metode manghafal al-Qur'an, antara lain adalah dengan metode menghafal dengan menambah materi hafalan itu lebih baik dari pada terus menerus tanpa henti-hentinya dalam suatu waktu, sebagaimana menurut HM. Arifin, M. Ed, sebagai berikut: "Suatu ingatan akan lebih mudah terbentuk bila dilakukan menurut pembagian waktu berulang-ulang. Belajar berulang-ulang akan lebih efektif dari pada terus menerus tanpa henti-hentinya dalam suatu waktu". ${ }^{20}$

3. Manfaat Tahfidhul Qur'an

a. Mendapat Kenikmatan Dunia

Menurut beberapa hadits, salah satu kenikmatan dunia adalah hafal dengan Al-Qur'an. Dengan menjaga Al-Qur'an, Allah senantiasa memberikan kemudahan baginya. Bahkan Allah izinkan hambanya untuk iri pada seseorang yang diberi kenikmatan hafal Al-Qur'an.



Artinya: "Tidak boleh seseorang berkeinginan kecuali dalam dua perkara, menginginkan seseorang yang diajarkan oleh Allah kepadanya Al-Qur'an kemudian ia membacanya sepanjang malam dan siang, sehingga tetangganya mendengar bacaannya, kemudian ia berkata, 'Andaikan aku diberi sebagaimana si fulan diberi, sehingga aku dapat berbuat sebagaimana si fulan berbuat',' (HR. Bukhari)

b. Mendapat Pahala Kebaikan

Manfaat menghafal Al-Qur'an selanjutnya adalah bertambahnya pahala kebaikan. Semua manusia berlomba untuk bisa memperoleh pahala. Pahala inilah yang akan menghantarkan manusia ke surga. Pahala diperoleh dari kebaikan yang dilakukan selama manusia hidup. Salah satunya dengan membaca dan menghafal Al-Qur'an. Allah pun akan lipat gandakan pahala ini bagi orang-orang yang rajin.

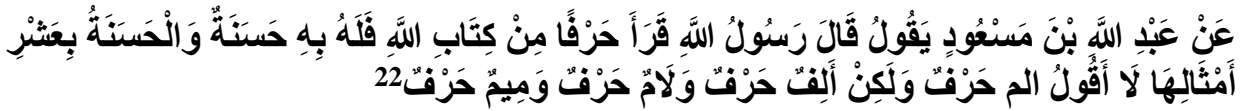

Artinya: Dari Abdullah bin Mas'ud berkata; Rasulullah bersabda: "Barang siapa membaca satu huruf dari Kitabullah (Al Qur`an), maka

${ }^{20}$ HM. Arifin, Hubungan Timbal Balik Pendidikan Agama di Lingkungan Sekolah dan Keluarga Sebagai Pola Pengembangan Metodologi, (Jakarta: Bulan Bintang,1976), 206.

${ }^{21}$ HR. Bukhari.

${ }^{22}$ HR. Tirmidzi. 
baginya satu pahala kebaikan dan satu pahala kebaikan akan dilipat gandakan menjadi sepuluh kali, aku tidak mengatakan Alif Laam Miim itu satu huruf, akan tetapi Alif satu huruf, Laam satu huruf dan Miim satu huruf'". (HR. Tirmidzi)

c. Mendapat Penghargaan dari Nabi SAW berupa Penghargaan Khusus Tasyrif Nabawi

Rasulullah sangat menghargai para hafidz Qur'an. Diberikannya berbagai keutamaan khusus. Seperti saat wafat akan didahulukan di kubur, dan juga dijadikan pemimpin delegasi atau pasukan khusus. Orang yang punya hafalan banyak pun diizinkan menjadi imam sholat berjamaah.

Adalah nabi mengumpulkan di antara dua orang syuhada Uhud kemudian beliau bersabda, "Manakah di antara keduanya yang lebih banyak hafal Al-Qur'an, ketika ditunjuk kepada salah satunya, maka beliau mendahulukan pemakamannya di liang lahat." (HR. Bukhari)



Artinya: Rasulullah SAW bersabda, "Yang menjadi imam suatu kaum adalah yang paling banyak hafalannya." (HR. Muslim)

Dari Abu Hurairah ia berkata, "Telah mengutus Rasulullah SAW sebuah delegasi yang banyak jumlahnya, kemudian Rasul mengetes hafalan mereka, kemudian satu per satu disuruh membaca apa yang sudah dihafal, maka sampailah pada Shahabi yang paling muda usianya, beliau bertanya, "Surat apa yang kau hafal? Ia menjawab, "Aku hafal surat ini.. surat ini.. dan surat Al Baqarah." Benarkah kamu hafal surat Al Baqarah?" Tanya Nabi lagi. Shahabi menjawab, "Benar." Nabi bersabda, "Berangkatlah kamu dan kamulah pemimpin delegasi." (HR. At-Turmudzi dan An-Nasa'i)

d. Mencerminkan Seseorang yang Memiliki Ilmu

Sebagaimana yang kita ketahui bersama bahwa orang berilmu punya nilai lebih. Karena, ilmulah yang menjaga seseorang. Dibandingkan harta, orang yang berilmu senantiasa punya jabatan lebih. Dalam Al-Qur'an pun, orang yang hafal Al-Qur'an sangat istimewa.

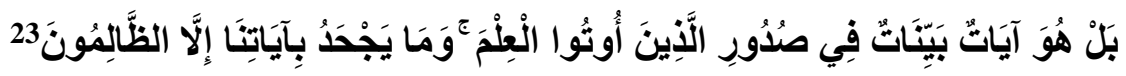

Artinya: "Sebenarnya, Al Qur'an itu adalah ayat-ayat yang nyata di dalam dada orang-orang yang diberi ilmu. Dan tidak ada yang mengingkari ayat-ayat Kami kecuali orang-orang yang zalim." (QS Al-Ankabuut 29:49)

e. Memberikan Derajat dan Wibawa yang Lebih Baik

Membaca Al-Qur'an akan membuat diri lebih berilmu. Dengan demikian, orang-orang pun akan menghormati penghafal Al-Qur'an. Seorang penghafal Al-Qur'an akan disenangi, disayangi, bahkan dikagumi banyak orang. Karena, ingin mencontoh kemampuannya. 


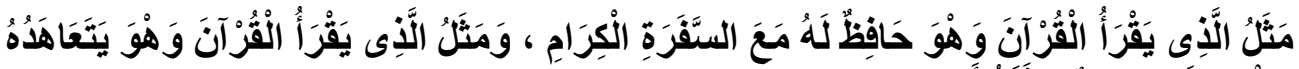

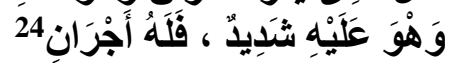

Artinya: "Orang orang yang hebat dalam membaca Al-Qur'an akan selalu ditemani para malaikat pencatat yang paling dimuliakan dan taat pada Allah SWT dan orang orang yang terbata-bata membaca AlQur'an lalu bersusah payah mempelajarinya maka dia akan mendapatkan dua kali pahala," (HR. Bukhari)

\section{Strategi Peningkatan Kompetensi Asatidz Al-Qur'an dalam Pembelajaran Tahfidz Qur'an Menyongsong Revolusi Industri 5.0}

Asatidz dan asatidzah bukan hanya yang berstatus sebagi pengajar Al-quran tetapi seluruh komponen masyarakat, peneliti, ataupun yang lainnya yang bergerak dalam bidang pendidikan untuk memberi ilmu pengetahuan, keterampilan, pembentukan sikap dan karakter untuk mencerdaskan kehidupan bangsa. Hadirnya revolusi industri yang menghadirkan teknologi dalam pembelajaran tahfidz dapat dimaknai dengan memproduksi sebuah produk teknologi contohnya alqur'an digital kemudian teknologi tersebut dapat dimanfaatkan oleh santri untuk menghafalkan al-qur'an, dan mampu menghadirkan alat bantu pembelajaran dan manajemen yang efektif dan efisien yang menjadi literasi pembelajaran tahfiz. Disinergikan untuk peningkatan kemampuan mengajar tahfidz Al-qur'an. Mengadopsi negara Jepang yang sudah mengimplementasikan revolusi 5.0 maka asatidz dan asatidzah harus memiliki kompetensi Society 5.0

1. Leadership yaitu kepimpinan untuk mempersiapkan karakter kuat khususnya dibidang leadership.

Peningkatan kompetensi leardership bagi asatidz dan asatidzah sebagai bekal dalam mengontrol peserta didik dan mampu menjadi suri tauladhan yang baik. Adapun peningkatan kompetensi ini dapat dilakukan dengan latihan kempimpinan Islam. Dengan cara mempelajari kempimpinan kyai atau kepimpinan kepala sekolah dimana asatidz dan asatidzah mendidik peserta didik dalam pembelajaran tahfidz.

2. Language Skills yaitu kemampuan berbahasa asing khusunya bahasa inggris.

Terkadang masih banyak penemuan bahwa asatidz dan asatidzah belum mampu menguasai bahasa inggris. Peningkatan language skills harus diberikan agar asatidz dan asatidzah memiliki kemampuan dalam menjelaskan arti Al Qur'an dala bahasa inggris. Hal tersebut dapat ditempuh dengan mengikutsertakan asatidz dan asatidzah dalam program pelatiha atau training bahasa inggris.

3. IT Literacy, dimana teknologi IT menjadi ciri utama era society 5.0

IT literacy ini sangat dibutuhkan. Dimana bukti itu untuk hafalan pembelajaran Alquran sangat dibutuhkan. Yang harus dilakukan asatidz dan asatidzah adalah mau membuka wawasan dan mempelajari tentang literasy digital baik audia, visual, maupun audio visual.Jadi peserta didik menghafalkan al-quran tidak harus duduk diam dan menyetorkan hafalan dan jangka waktu sekian jam.

${ }^{24}$ HR. Bukhari. 
Disini pembekalan tetang teknologi wajib dipunyai oleh asatidz dan asatidzah guna peningkatan kompetensi paedagogik.

4. Writting Skills, kegiatan menulis penting untuk menuangkan ide dan gagasan yang dimiliki dan pemikiran maupun inovasi baru dapat ditularkan kepada society 5.0

Walaupun pembelajaran hafalan Al-Qur'an, asatidz dan asatidzah harus memiliki kemampuan menulis maka dari itu harus memiliki latar belakang pendidikan guru, pengalaman guru dalam mengajar juga turut mempengaruhi kompetensi guru karena dengan pengalaman, seorang akan mudah dalam melakukan suatu tindakan atau pekerjaan. Dengan demikian, maka pengalaman mengajar bagi guru itu sangat besar pengaruhnya dalam pengetahuan serta keterampilan menulis. Jadi, asatidz dan asatidzah memiliki karya tulis misalnya 101 Cara menghafal kilat ayat-ayat al-qur'an.

Strategi yang harus dilakukan dalam peningkatan kompetensi asatidz dan asatidzah adalah training bahasa inggris dan IT secara berkelanjutan, kepemimpinan kyai atau manajerial yang sesuai eranya, fasilitas asrama yang lengkap dengan teknologi mutakhir, peningkatan keprofesian berkelanjutan dan lesson study dengan dukungan e-literasi, dan regulasi tentang standar kompetensi asatidz dan asatidzah di Indonesia

1. Training bahasa inggris dan IT secara berkelanjutan yang harus dilakukan asatidz dan asatidzah harus rutin dilakukan

Training atau Penataran disebut juga dengan upgrading, ialah segala usaha atau kegiatan yang bertujuan untuk meninggikan atau meningkatkan taraf ilmu pengetahuan dan kecakapan para pegawai, guru-guru atau petugas pendidikan lainnya, sehingga dengan demikian keahliannya bertambah luas dan mendalam. Sering tidaknya guru mengikuti penataran merupakan salah satu hal yang mempengaruhi peningkatan kualitas guru, penataran memuat beberapa unsur, ada unsur individual (pada waktu melaksanakan tugas individual), unsur kelompok (waktu berdiskusi) dan unsur tulisan (waktu membuat laporan dan lain-lain) utamanya training dalam bidang bahasa inggris dan IT

2. Kempimpian Kyai atau Manajerial

Kyai adalah sosok yang sangat berpengaruh dalam peningkatan kompetensi asatidz dan asatidzah. Ketika kyai yang menaungi dalam institusi pembelajaran tahfidz memiliki pengaruh dan persuasif terhadap peningkatan kompetensi asatidz dan asatidzah maka akan ada persiapan yang signifikan terhadap tantangan zaman di resolusi 5.0. karena kempimpinan didapatkan salah satunya dari keinginan asatidz dan asatidzah menjadi pemimpin yang baik buat peserta didiknya.

\section{Fasilitas Asrama Lengkap Dengan Teknologi Modern}

Kemampuan seseorang dapat bertambah jika dipengaruhi lingkungannya. Demikian juga dengan dengan asatidz dan asatidzah yang hanyalah 


\section{$\ell^{L-T a r b a w j}$}

manusia biasa. Dimana dibentuk oleh lingkungan yang mereka ditinggali. Jika fasilitas asrama yang ditinggali asatidz atau asatidzah lengkap dengan teknologi modern, maka setoran hafalan tidak harus dilakukan dengan tatap muka dapat melalui video teleconfere dan media canggih lainnya sehingga asatidz dan asatidzah dapat selalu mengupgrade ilmu pengetahuannya dan hafalan al quran.

4. Peningkatan Keprofesian Berkelanjutan dan lesson study dengan dukungan e-literasi.

Sama hanya dengan guru di lembaga umum, guru hafalan al-qur'an juga harus ada pendidikan keprofesian berkelanjutan yang akan berguna untuk kefasihan bacaan, penguasaan pembuatan teknologi untuk generasi qur'ani seperti hafidz doll yang dapat dimanfaatkan oleh anak-anak untuk menghafalkan alqur'an, terlebih lagi pembuatan Alquran berbasis digital dan e-literasi lainnya yang berhubungan dengan peningkatan minat anak dalam menghafalkan alqur'an.

5. Regulasi tentang standar kompetensi asatidz dan asatidzah di Indonesia

Belum dibuatnya standar khusus untuk asatidz dan asatidzah menjadikan standar kemampuan asatidz dan asatidzah itu bervariasi. Apalagi ada diskursi aliran dalam Islam yang semakin mengklasifikasikan standar kompetensi guru Alquran itu berbeda-beda. Maka diperlukan segera regulasi untuk menyongsong resolusi 5.0. Sebagai bentuk basic data tentang kompetensi dalam mengajar hafalan alqur'an

\section{Kesimpulan}

Mengadopsi kompetensi 5.0 diantaranya adalah leadership yaitu kepimpinan untuk mempersiapkan karakter kuat khususnya dibidang leadership, language Skills yaitu kemampuan berbahasa asing khusunya bahasa inggris, IT Literacy, dimana teknologi IT menjadi ciri utama era society 5.0 dan Writting Skills, kegiatan menulis penting untuk menuangkan ide dan gagasan yang dimiliki dan pemikiran maupun inovasi baru dapat ditularkan kepada society 5.0

Didapatkan strategi peningkatan kompetensi asatidz dan asatidzah dalam pembelajaran tahfidz adalah training bahasa inggris dan IT secara berkelanjutan, kepemimpinan kyai atau manajerial yang sesuai eranya, fasilitas asrama yang lengkap dengan teknologi mutakhir, peningkatan keprofesian berkelanjutan dan lesson study dengan dukungan e-literasi, dan regulasi tentang standar kompetensi asatidz dan asatidzah di Indonesia 


\section{Daftar Pustaka}

Adnan,Muhammad, 2009. Ke Nuan MTs/SMP Kelas VIII. LP: NU.

Arifin, HM. 1976.Hubungan Timbal Balik Pendidikan Agama di Lingkungan Sekolah dan Keluarga Sebagai Pola Pengembangan Metodologi.Jakarta: Bulan Bintang

B. Agung Hartono, Sunarto1999. Perkembangan Peserta didik. Jakarta: Depdiknas dan PT Cipta.

Imam Abu Yahya Bin Syaraf An-Nawawi,At-Tibyan Adab Para Penghafal Al-Qur'an, Terj. Nawabuddin, Abdurrab. 1991. Tekhnik Menghafal Al-Qur'an. Bandung: Sinar Baru.

Makhyaruddin, D.M . 2013. Rahasia Nikmatinya Menghafal Al-Qur'an .Jakarta: Mizan Publika.

Rauf, Abdul Aziz Abdul.2004. Kiat Sukses Menjadi Hafidz Qur;an Daiyah. Bandung: Syamil Cipta Media.

Rauf, Abdul Aziz Abdul.2004. Kiat Sukses Menjadi Hafidz Qur;an Daiyah. Bandung: Syamil Cipta Media.

Supramono, M.Diaz Bony, Urgensi Society 5.0 di Era Revolusi Industri 4.0 dalam https://www.kompasiana.com/diaz.bonny/5c4f90f5677ffb5363300e24/urgesisociety-5-0-di-era-revolusi-industi-4-0 diakses pada 6 April 2019 jam 13.13

Tafsir, Ahmad. 1991. Ilmu Pendidikan Dalam Persepektif Islam .Bandung: PT Remaja Rosdakarya

Ulin Nuha Mahfudhon.2017. Jalan Penghafal Al-Qur'an. Jakarta: Kompas Gramedia.

Usman. User Algensindo2001. Menjadi Guru Professional, Bandung: Remaja rosdakarya. 